\section{GENRE-BASED APPROACH IN TEACHING BIPA}

\section{PENDEKATAN BERBASIS GENRE DALAM PENGAJARAN BIPA}

\author{
Basori', Elva Riezky Maharany ${ }^{2}$ \\ ${ }^{1}$ Universitas Islam Negeri Maulana Malik Ibrahim Malang \\ ${ }^{2}$ Universitas Islam Malang \\ 3 Basori@uin-malang.ac.id
}

Jurnal Pendidikan Luar Sekolah

http://kolokium.ppj.unp.ac.id/ Jurusan Pendidikan Luar Sekolah

Fakultas Ilmu Pendidikan

Universitas Negeri Padang

Sumatera Barat, Indonesia

Volume 9, Nomor 2, 2021

DOI:

Received 10 August 2021

Approved 25 August 2021

Published 15 October 2021

\begin{abstract}
Knowledge of various teaching strategies is one of the important things that teachers need to have. In this case, every teacher must equip themselves with a variety of teaching strategies to achieve success in teaching Indonesian to foreign speakers (BIPA). The text-based approach is one of the approaches that teachers can apply in teaching BIPA. There have been many studies that prove the success of this approach. However, the use of text-based approaches to teaching BIPA is still rare. Therefore, this article aims to provide a brief overview of the use of a text-based approach in teaching BIPA. The method used in this article is a qualitative review, with a case study approach. This paper will present an understanding of a text-based approach in general, the advantages of using a text-based approach in teaching BIPA, and examples of using a text-based approach in teaching BIPA.
\end{abstract}

Keywords: BIPA Teaching, Lesson Plan, Genre-based Approach

\begin{abstract}
ABSTRAK
Pengetahuan tentang ragam strategi pengajaran ialah salah satu hal penting yang perlu dimiliki oleh pengajar. Dalam hal ini, setiap pengajar harus membekali diri dengan ragam strategi pengajaran untuk mencapai keberhasilan dalam pengajaran Bahasa Indonesia bagi penutur Asing (BIPA). Pendekatan berbasis teks adalah salah satu dari pendekatan yang pengajar bisa terapkan dalam pengajaran BIPA. Telah banyak penelitian yang membuktikan kesuksesan pendekatan ini. Akan tetapi, penggunaan pendekatan berbasis teks pada pengajaran BIPA masih jarang ditemukan. Oleh karena itu, artikel ini bertujuan untuk memberikan gambaran singkat tentang pengggunaan pendekatan berbasis teks dalam pengajaran BIPA. Metode yang digunakan dalam artikel ini adalah kualitatif review, dengan pendekatan studi kasus. Artikel ini akan menyajikan pengertian pendekatan berbasis teks secara umum, keuntungan pemakaian pendekatan berbasis teks dalam pengajaran BIPA, dan contoh pemakaian pendekatan berbasis teks dalam pengajaran BIPA.
\end{abstract}

Kata Kunci: Pendekatan Berbasis Genre, Pengajaran BIPA, Rencana Pembelajaran (RPP) 


\section{PENDAHULUAN}

Guru menjadi salah satu ujung tombak keberhasilan seorang siswa dalam belajar (Turner, 2016). Guru bertugas merancang kelas sedemikian rupa guna mencapai tujuan pembelajaran. Beberapa indikator guru yang baik adalah mereka yang tidak terpaku pada satu jenis strategi atau teknik mengajar agar murid tidak bosan dalam proses belajar mengajar (Lunenburg dan Irby, 2011) dan hal tersebut tertuang dalam kemampuan guru dalam membuat rencana pembelajaran (Farrel, 2002). Pada makalah yang berjudul Instructional Strategies to Facilitate Learning, Lunenburg dan Irby sepakat bahwa strategi pengajaran ikut andil besar dalam mencapai keberhasilan seorang siswa dalam belajar (2011). Variasi teknik mengajar berdampak pada motivasi siswa dalam belajar (Varuzza, Sinatra, Eschenauer, dan Blake, 2014). Dengan kata lain, pengetahuan tentang ragam strategi pengajaran ialah salah satu hal penting yang perlu dimiliki oleh seorang guru. Tanpa strategi pengajaran yang tepat, proses transfer atau belajar ilmu tidak akan tercapai dengan sempurna (Ali, Idrees, dan Iftikhar, 2009). Kondisi ini mengakibatkan tujuan akhir pembelajaran tidak akan tercapai dengan sempurna (Sangoleye, 2016). Oleh karena itu, pemanfaatan ragam strategi pengajaran mutlak diperlukan oleh seorang guru dalam kegiatan mengajar mereka.

Ragam strategi pengajaran tersebut diterjemahkan dalam membuat salah satu perangkat pembelajaran, yaitu rencana pembelajaran (RPP). RPP adalah sebuah rencana pengajaran yang dibuat guru dalam mencapai tujuan pembelajaran (Farrel, 2002). Tanpa sebuah rencana pembelajaran, guru tidak akan kesulitan dalam menyampaiakan materi, menentukan ragam aktivitas, dan membagi waktu pengajaran (Purgason, 1991; Sulistyarini, 2016). Hasilnya pembelajaran tidak akan efektif (Inderasari dan Agustina, 2017). Dengan kata lain, RRP menjadi senjata bagi guru untuk mencapai kesuksesan pembelajaran.

Model pengajaran berbasis teks atau yang lebih dikenal dengan istilah Genre-Based Approach bukan menjadi hal yang asing di dunia belajar mengajar terutama pemanfaatannya di pengajaran bahasa kedua atau bahasa asing (Azaz, 2016; Badger dan White, 2000; Dirgeyasa, 2016; Kim, 2006; Reppen, 1994; Yang, 2016). BIPA sendiri diajarkan sebagai mata pelajaran pada sektor formal jenjang pendidikan dasar, menengah, atau tinggi maupun pada sektor pendidikan non-formal seperti yang dilakukan di banyak lembaga pendidikan nonformal di Indonesia, contohnya adalah Wisma Bahasa Yogyakarta, APBIPA Bali, dan IALF. Walapun banyak riset telah membuktikan keberhasilan dalam memanfaatkan model pengajaran berbasis teks, pemanfaatan pendekatan ini dalam pengajaran Bahasa Indonesia bagi Penutur Asing (BIPA) masih belum maksimal. Hal tersebut tampak pada belum atau kurangnya penelitian yang mengusung topik model pengajaran berbasis teks dalam pengajaran BIPA. Penelitian yang selama ini dilakukan lebih pada studi kasus pengajaran BIPA di suatu tempat (contoh: Azizah, Hs, dan Lestari, 2012; Sulistyarini, 2016; Inderasari dan Agustina 2017; Sari, Sutama, dan Utama, 2016), pengajaran BIPA pada level tertentu (contoh: Tiawati dan Lina, 2018), atau pembelajaran skill tertentu (contoh: Rosita, 2019; Jazeri, 2016). Dengan demikian rencana pembelajaran dengan memakai pendekatan berbasis teks belum mencuat ke permukaan.

Berdasar pada pentingnya variasi teknik pengajaran dalam mencapai kesuksesan belajar siswa dan kurangnya pemanfaatan model pengajaran berbasis teks dalam pengajaran BIPA menjadi dasar utama riset ini. Hal ini dilakukan untuk memberikan gambaran singkat tentang pengggunaan pendekatan berbasis teks dalam pengajaran BIPA. Riset ini akan menyajikan ragam studi terdahulu tentang rencana pembelajaran dalam pengajaran BIPA, pengertian pendekatan berbasis teks secara umum, keuntungan pemakaian pendekatan 
berbasis teks dalam pengajaran BIPA, serta pemakaian pendekatan berbasis teks dalam pengajaran BIPA melalui contoh pembuatan rencana pembelajaran (RPP).

\section{METODE}

Metode merupakan langkah-langkah yang dilakukan oleh peneliti untuk mengumpulkan data dalam membuat sebuah penelitian. Pada artikel ini, metode yang digunakan merupakan metode kualitatif review, yang diambil dari beberapa buku sumber yang relevan dan berdasarkan kasus yang terjadi di lapangan. Pembelajaran BIPA yang dilakukan oleh salah satu LPK di Yogykarta menggunakan Genre Basis Approach.

\section{PEMBAHASAN}

\section{Rencana Pembelajaran}

Dalam sebuah kurikulum, seorang pengajar wajib menyiapkan segala bentuk perangkat pembelajaran. Tanpa perangkat pembelajaran, pembelajaran tidak akan sesuai dengan kebutuhan siswa dan situasi yang ada (Nation, \& Macalister, 2010; Richards, 2001). Salah satu komponen penting dari sebuah perencanaan pembelajaran adalah rencana pembelajaran (RPP). RPP tersebut menjadi acuan bagi guru tentang bagaimana kegiatan belajar mengajar akan dilakukan (Sari, Sutama, \& Utama, 2016). Dengan kata lain, tanpa RPP, kegiatan belajar mengajar tidak akan berjalan dengan sempurna. Hal ini tidak bisa dipungkiri jika RPP masih menjadi salah satu topik penting dalam pelatihan para pengajar (Kusmiatun dan Pratiwi, 2019).

Penelitian Sulistyarini (2016) dan penelitian oleh Inderasari dan Agustina (2017) menjadi contoh pentingnya sebuah RPP dalam pengajaran. Dalam penelitiannya, Sulistyarini (2016) menemukan bahwa pengajar BIPA di tempat yang ia teliti tidak wajib membuat RPP. Akibatnya, pembelajaran mengalami kendala. Hal yang sama juga dikemukakan oleh Inderasari dan Agustina (2016). Pembelajaran BIPA menjadi tidak efektif ketika RPP tidak dibuat. Dari kedua penelitian tersebut dapat disimpulkan bahwa tanpa adanya RPP, kegiatan belajar mengajar mengalami kendala seperti tidak tercapainya tujuan pembelajaran sehingga program pengajaran BIPA kurang sempurna terutama pada penguasaan bahasa para siswa.

Dalam pengajaran BIPA, penelitian yang memusatkan pada pentingnya RPP dalam pengajaran masih dilakukan. Sari, Sutama, dan Utama (2016) melakukan penelitian yang bertujuan mendeskripsikan perencanaan pembelajaran BIPA di salah sekolah bahasa. Dari penelitian yang mereka lakukan, salah satu temuan penting penelitian adalah peran silabus yang menunjang para guru pengajar untuk melaksanakan pengajaran yang sistematis (Sari, Sutama, dan Utama, 2016). Hal yang sama juga diutarakan oleh Artayasa, Sutama, dan Utama (2017) yang juga melakukan penelitian dengan tajuk yang sama. Secara spesifik pada penelitian kualitatif tersebut, mereka menyatakan bahwa RPP, terutama pada pembagian waktu pembelajaran, memudahkan guru dalam memenejemen pembelajaran. Dengan alokasi waktu yang sudah direncanakan, guru akan terhindar dari kekurangan atau kelebihan jam pelajaran (Artayasa, Sutama, dan Utama, 2017). Tiawati dan Lina (2018) menambahkan bahwa pengajaran BIPA merupakan bagian dari sebuah sistem pengajaran dengan tujuan yang terarah dan terukur. Sistem tersebut termasuk didalamnya adalah pembuatan perangkat pembelajaran, yaitu sebuah RPP. 
Meskipun banyak penelitian yang mengankat RPP sebagai topik bahasan, penelitian yang berfokus pada pembuatan RPP dengan menggunakan pendekatan berbasis teks masih minim atau bahkan dapat dikatakan belum ada. Oleh sebab itu, pendekatan berbasis teks dalam pembuatan RPP diangkat dalam tulisan ini. Hal ini juga sebagai bentuk pengembangan penelitian sebelumnya yang berfokus pada penelitian pengembangan RPP menggunakan pendekatan lain (Jazeri, 2016; Rosita, 2019)

\section{Pendekatan Berbasis Teks}

Penggunaan pendekatan berbasis teks dalam pengajaran bahasa dikembangkan pertama kali di Australia (Nugroho dan Hafrizon, 2009). Para ahli bekerjasama membuat metode pengajaran untuk membantu siswa belajar bahasa (NSW Department of School Education, 1989). Genre sendiri dimaknai sebagai "systemic functional linguistics that is concerned with the relationship between language and its functional in social setting" (Hyon, 1996, p. 696). Hal ini berarti bahwa dalam sebuah teks akan ditemukan fitur-fitur kebahasaan yang menjadi ciri teks tersebut. Sebagai contoh, teks narasi akan berbeda fitur kebahasaannya dengan teks prosedur. Secara lebih spesifik, penggunaan teks dalam penyusunan materi belajar membantu siswa dalam 3 hal, yaitu memahami penggunaan ragam bahasa tulis dalam konteks (the social contexts in which the language is used), struktur ragam bahasa tulis (the way written texts are structured), dan tata bahasa (the grammar of the written language) (Scott dalam NSW Department of School Education, 1989). Berdasarkan hal tersebut, genre yang dibuat sebagai sebuah pendekatan dalam belajar akan mengarahkan siswa dalam penguasaan struktur teks dan tata bahasa yang sangat diperlukan oleh siswa untuk memproduksi ragam teks yang kontekstual.

Pada pendekatan berbasis teks, kurikulum model pengajaran dibagi menjadi 3 tahapan yang dilakukan secara berurutan yaitu (1) Modelling, (2) Joint Negotiation of a Text, dan (3) Independent Instruction of a Text (NSW Department of School Education, 1989). Pada perkembangannya, Hammond and Macken-Horarik (in Yang, 2016) membagi tahapan menjadi 4 yaitu (1) Building Knowledge of the Field, (2) Modelling, (3) Joint Negotiation of a Text, dan (4) Independent Instruction of a Text. Setiap tahapan terdapat ragam aktivitas yang melibatkan kerjasama antara guru dengan siswa atau siswa dengan siswa.

Tahapan pertama dalam pendekatan berbasis teks adalah Building Knowledge of the Field. Pada tahapan ini, semua aktivitas belajar mengajar ditujukan untuk membangun pengetahuan siswa terhadap teks yang akan mereka pelajari dengan cara mengenalkan ragam konteks yang akan dipakai. Ragam kegiatan yang bisa dilakukan dalam tahapan ini adalah curah pendapat (brainstorming), membaca ragam sumber yang relevan atau perbandingan lintas budaya (cross-cultural comparisons) (Dickinson, 2013, p. 4). Pada tahap ini, pembahasan mengenai pola leksikal grammatikal (lexical-grammatical patterns) juga diberikan (Yang, 2016, p. 39). Selain itu, kosakata serta tata bahasa terkait dengan teks yang dibahas juga dikenalkan pada tahapan ini (Hammong \& Macken-Horarik in Yang, 2016; Maharany, 2020). Kerjasama antara guru dan murid tampak pada semua aktivitas di tahapan ini seperti pada kegiatan berdiskusi dan curah pendapat. Kegiatan ini menjadi dasar penting bagi siswa sebelum mereka ke tahap pemodelan (Modelling). Tanpa dasar yang kuat, siswa akan mengalami kesulitan untuk mencapai tahapan yang lebih tinggi.

Setelah mendapatkan pengetahuan yang kuat pada tahap Building Knowledge of the Field, siswa kemudian diarahkan untuk ke tahap pemodelan (Modelling). Ragam kegiatan dalam tahapan ini diantaranya adalah pemberian contoh ragam teks dengan tujuan 
komunikasi yang sama. Sebagai contoh, teks prosedur yang digunakan untuk membuat masakan, mencuci baju, mendaftar sekolah, atau prosedur dalam mengurus visa. Walapun berbeda konteks, semua contoh teks prosedur tersebut mempunyai tujuan komunikatif yang sama, yaitu memberikan cara atau instruksi. Karena siswa mengenal ragam contoh teks, secara tidak langsung, fungsi sosial, konteks sosial, struktur dari teks, fitur-fitur kebahasaan, dan kosakata terkait teks juga dibahas dalam tahapan ini (Dickenson, 2013; Dirgeyasa, 2016; Yang, 2016; Maharany, 2020). Seperti yang disampaikan oleh Dickenson (2013), mengonstruksi ulang merupakan kata yang tepat untuk dipakai dalam tahapan ini karena guru berperan penting dalam memahamkan siswa secara lebih rinci tentang sebuah teks, mulai dari tujuan komunikasi sampai kosakata kunci yang sering dipakai untuk menyusun sebuah teks. Dirgeyasa (2016) berpendapat bahwa keberagaman contoh teks yang diberikan pada tahapan ini diharapkan mampu menyesuaikan kebutuhan siswa.

Baik tahap Building Knowledge of the Field maupun tahap pemodelan (Modelling) berperan penting dalam memberikan dasar pemahaman siswa terhadap sebuah teks. Pada tahapan tersebut, kontribusi besar guru sangat berpengaruh dalam kesuksesan belajar siswa. Guru menjadi kunci utama membangun pengetahuan yang kuat agar tujuan pembelajaran tercapai (Reppen, 1995). Guru tidak hanya harus menyiapkan materi belajar tetapi juga fasilitas penunjang lain dalam belajar. Berdasarkan hal tersebut maka peran guru tidak hanya diperlukan sebagai satu-satunya sumber belajar, akan tetapi mereka juga dituntut sebagai penuntun dan fasilitator belajar siswa. Berdasarkan hal tersebut maka tahapan Building Knowledge of the Field dan pemodelan (Modelling) membutuhkan alokasi waktu yang lebih dibandingkan tahapan yang lain (NSW Department of School Education, 1989). Berdasar dari pernyataan tersebut dapat disimpulkan bahwa guru berperan penting dalam menciptakan ragam kegiatan yang berdampak langsung dalam menunjang keberhasilan siswa dalam memahami teks.

Tahapan selanjutnya adalah Joint Negotiation of the Text. Pada tahapan ini, siswa dan guru akan bekerjasama untuk membuat jenis teks yang sama dengan yang dibahas pada tahap pemodelan. Yang (2016) menambahkan bahwa sangat dimungkinkan terjadinya kerjasama antar murid dalam mengonstruksi ulang dan membuat teks baru. Pada proses tersebut siswa diminta untuk menggunakan pengetahuan dan keterampilan yang mereka kuasai ketika proses Building Knowledge of the Field dan pemodelan (Modelling). Pada tahap ini, pengetahuan dan keterampilan siswa terasah karena mereka praktik membuat sebuah teks. Akan tetapi, pembuatan teks dalam tahapan ini lebih pada memodifikasi teks yang telah mereka pelajari (Dirgeyasa, 2016). Pada tahap ini juga, kerjasama antar siswa atau siswa dengan guru dimungkinkan terjadi sharing knowledge yang membantu siswa untuk menambah pengetahuan dan keterampilan mereka dalam menguasai teks. Selain itu, siswa berkesempatan untuk praktik pemakaian tata bahasa, struktur teks dan kosakata khusus yang berkaitan dengan topik untuk membuat teks (NSW Department of School Education, 1989). Dengan demikian, ragam aktivitas dalam proses belajar mengajar yang dirancang oleh guru diharapkan dapat mendukung siswa dalam kegiatan tersebut. Jika ditarik kesimpulan, tahap Joint Negotiation of the Text mencakup kegiatan yang meminta siswa untuk bekerjasama dalam merekonstruksi sebuah teks dengan bimbingan guru sebelum mereka berlanjut ke tahap siswa secara individu membuat teks mereka sendiri.

Tahap terakhir dalam pendekatan berbasis teks adalah Independent Construction of Text. Pada tahap ini, siswa secara individu membuat teks. Siswa diberikan kebebasan untuk membuat teks dengan genre yang sama pada tahap sebelumnya. Akan tetapi, siswa diberikan 
kebebasan untuk memilih topik yang mereka suka. Pada tahap ini, siswa juga diperbolehkan untuk melakukan konsultasi dengan teman atau dengan guru selama proses pembuatan teks. Oleh karena itu, kegiatan siswa dimulai dari pembuatan rancangan, guru memberikan masukan, revisi, sampai teks yang dibuat sempurna, baik dari segi stuktur maupun kebahasaannya.

Pendekatan berbasis teks terdiri empat tahapan yang dimulai dari Building Knowledge of the Field, kemudian tahap pemodelan (Modelling). Kedua tahap ini menjadi kunci utama keberhasilan pemahaman siswa terrhadap sebuah genre. Berikutnya tahap Joint Negotiation of Text, pada tahap ini keberhasilan siswa dalam membuat replika teks merupakan penanda bahwa mereka siap untuk menuju tahap terakhir, yaitu Independent Construction of Text. Meskipun dalam teori tahapan-tahapan tersebut berbentuk sebuah siklus yang berurutan, guru diperbolehkan untuk mengulang tahapan tertentu jika hal tersebut diperlukan (Badger dan White, 2000).

\section{Keuntungan Pemakaian Pendekatan Berbasis Teks dalam Pengajaran BIPA}

Banyak penelitian terdahulu yang mengangkat isu pendekatan berbasis teks dalam pengajaran bahasa asing atau bahasa kedua. Ini menjadi bukti bahwa pendekatan tersebut banyak dipakai dan bermanfaat dalam pengajaran bahasa. Berdasar pada tahapan-tahapan yang ada dalam pendekatan berbasis teks, berikut empat keuntungan pemakaian pendekatan ini dalam pengajaran BIPA. 1) Pendampingan (Guided process), Pada pendekatan berbasis teks, siswa tidak hanya berorientasi pada produk akhir yaitu sebuah teks, tetapi juga pada proses pembuatan teks itu sendiri. Untuk menghasilkan sebuah teks yang utuh, selain siswa belajar sendiri atau belajar melalui teman, mereka juga dibimbing dan diarahkan oleh guru. Siswa dipandu mulai dari tahap awal pengenalan teks sampai mereka dapat menghasilkan teks secara individu. Akan tetapi, peran guru akan berubah seiring dengan perubahan tahapan. Kontribusi guru terhadap kelas terlihat menonjol terutama di dua tahap awal yang kemudian menjadi lebih berkurang di dua tahap akhir yang memerankan guru sebagai fasilitator dan motivator dalam belajar; 2) Mendukung terciptanya kegiatan belajar baik kelompok maupun individu. (Foster both group work and individual study), 3) Seperti yang dikatakan oleh Nugroho dan Hafrizon (2009), pendekatan ini sangat menitikberatkan pada kerjasama dan interaksi baik antar siswa maupun siswa dengan guru dalam memahami dan membuat teks. Selain itu, siswa dapat mengasah keterampilan berkomunikasi mereka melalui curah pendapat dan bertukar gagasan selama proses belajar mengajar. Hal ini akan sangat terlihat pada tahap Joint Negotiation of Text di mana mereka berkolaborasi mendekonstruksi dan membuat teks secara berkelompok. Selain itu, rasa tanggungjawab juga terbangun karena mereka secara individu menghasilkan sebuah teks pada tahapan Independent Construction of Text. Dengan demikian, pendekatan ini juga membangkitkan motivasi siswa dalam belajar (Dirgeyasa, 2016); 4) Mendukung Pembelajaran yang Bermakna bagi Siswa (Meaningful learning), Pada setiap tahapan yang ada, siswa akan belajar konteks sosial yang berasal dari teks yang akan dipakai. Pada pemodelan misalnya, mereka belajar dari ragam sumber yang ada di sekitar mereka seperti majalah, surat kabar, atau acara memasak di sebuah stasiun televisi. Dengan demikian, apa yang mereka pelajari dan mereka hasilkan akan bermakna. Dengan pembelajaran bermakna, mereka tidak hanya mempunyai kemampuan untuk mengingat, atau menghafal melainkan mereka berkesempatan untuk menganalisa, mengaplikasikan keterampilan dan pengetahuan yang mereka dapat untuk memproduksi sebuah teks. Kegiatan tersebut berdampak pada pemahaman yang utuh dalam diri siswa (Mayer, 2002); 5) Pemerolehan Keterampilan Reseptif dan Produktif, Pendekatan berbasis teks mendukung 
siswa untuk mengasah keterampilan siswa dalam menyimak, membaca, berbicara, dan menulis (Yang, 2016). Di dua tahapan awal pendekatan ini, siswa dikenalkan dengan teks. Tidak hanya bertumpu pada penjelasan dari guru, siswa diminta untuk aktif membaca, menyimak, dan mencari materi dari sumber belajar lain. Selain itu, siswa juga aktif melakukan diskusi dan menerima masukan baik dari teman maupun dari guru. Di tahap akhir, siswa membuat sendiri teks mereka, kegiatan tersebut juga masih dimungkinkan untuk dilakukan. Dengan kata lain, kemampuan reseptif dan produktif mereka terasah.

Meskipun banyak studi yang membuktikan bahwa pendekatan berbasis teks mempunyai banyak keuntungan dalam pengajaran bahasa asing, tetapi pendekatan ini belum banyak digali dalam pengajaran BIPA. Oleh karena itu, makalah ini menyajikan pemanfaatan pendekatan berbasis teks dalam pengajaran BIPA melalui contoh rencana pembelajaran yang menerapkan pendekatan berbasis teks dalam pengajaran BIPA.

\section{Lesson Plan}

\section{Pemakaian Pendekatan Berbasis Genre dalam Pengajaran BIPA}

Berdasarkan keuntungan pendekatan yang telah dipaparkan di atas, makalah ini akan memberikan contoh penggunaan pendekatan tersebut pada pengajaran BIPA melalui pembuatan Rencana Pelaksanaan Pembelajaran (RPP) yang dapat dipakai guru dalam mengajar. RPP ini dirancang sesuai dengan kaidah pembuatan RPP yang terdiri dari identitas, tujuan pembelajaran, materi pembelajaran, metode pembelajaran, tahapan kegiatan pembelajaran sesuai dengan pendekatan berbasis teks dan jumlah pertemuan yang ada, media pembelajaran, dan evaluasi pembelajaran. Komponen tersebut sesuai dengan standar minimal komponen sebuah RPP mulai dari identitas hingga penilaian (Sari, Sutama, \& Utama, 2016).

Pada contoh RPP yang diberikan, Dapur Indonesia dipilih sebagai topik yang dipakai untuk mengajarkan salah satu bentuk teks yaitu prosedur. RPP ini dirancang untuk siswa pada tingkatan Madya sesuai dengan pedoman kemahiran yang disusun oleh American Council on the Teaching of Foreign Languages (ACTFL). Pada tingkatan madya, siswa sudah memiliki kemahiran berbahasa yang mumpuni untuk bisa berbicara tetang topik yang berhubungan dengan kehidupan sehari-hari sehingga produksi bahasa mereka dapat dipahami dengan baik (ACTFL, 2012).

RPP ini dirancang untuk pengajaran siswa pada tingkatan Madya terutama pada level Madya Menengah. Diharapkan nantinya, RRP tersebut dapat mengarahkan siswa untuk mencapai tingkatan yang lebih tinggi minimal pada level Madya Tinggi atau pada level Mahir Rendah. Akan tetapi, walaupun RPP tersebut dirancang untuk guru mengajar di level Madya Menengah, guru masih dapat melakukan modifikasi materi pengajaran sesuai dengan tingkatan kompetensi siswa yang diajar atau disesuaikan dengan kebutuhan. Urutan tahapan kegiatan dan ragam aktivitas dalam setiap kegiatan masih dapat menjadi rujukan dalam membuat RPP sesuai kebutuhan kelas pada tingkatan yang diinginkan. Selain itu, RPP ini dapat dipakai sebagai referensi untuk membuat RRP pengajaran bentuk teks yang lain. Contoh materi juga disajikan untuk mendapatkan gambaran yang utuh sebuah RPP.

RPP ini bertujuan untuk mengajarkan siswa menulis teks berbentuk prosedur dengan topik yang sama. Selain itu, siswa dapat belajar tentang budaya Indonesia terutama ragam kuliner. RPP tersebut terbagi menjadi 4 tahapan yaitu, Building knowledge of the field, Pemodelan (Modelling), Joint Construction of the Text, dan Independent Construction of the Text, tiap-tiap tahapan mempunyai fungsi dan tujuan yang berbeda. 
RPP ini dirancang untuk 4 pertemuan sesuai dengan tahapan pada pendekatan berbasis teks. Durasi dari tiap pertemuan adalah 2 x 40 menit. Untuk pertemuan pertama, titik berat dari kegiatan belajar mengajar adalah membangkitan pengetahuan siswa untuk diarahkan pada topik atau materi yang akan dibahas, yaitu teks prosedur. Ragam kegiatan yang diberikan bertujuan untuk menggali pengalaman dan pengetahuan yang dimiliki siswa yang berkaitan dengan topik yang dibahas. Hasil dari kegiatan ini dapat memudahkan siswa untuk memahami materi yang akan dibahas. RPP pada pertemuan pertama juga menyertakan contoh aktivitas pada kegiatan awal dan kegiatan penutup yang dapat dijadikan rujukan untuk merancang ragam kegiatan pada pertemuan di tahapan-tahapan kegiatan berikutnya.

Tahapan berikutnya adalah pemodelan. Pada tahapan ini, fokus dari kegiatan pengajaran adalah memberikan ragam contoh teks prosedur kepada pemelajar. Pada RPP yang diberikan, siswa diajak untuk mengenal lebih jauh tentang sebuah teks prosedur melalui kegiatan analisis sebuah teks. Ragam contoh pertanyaan lisan diberikan pada RPP. Melalui kegiatan pemodelan, siswa diharapkan dapat memahami dengan baik sebuah teks prosedur baik dari segi struktur, tata bahasa maupun, fungsi sosialnya.

Setelah pemodelan, tahapan selanjutnya adalah kegiatan pembuatan teks secara berkelompok (Joint Construction of the Text). Pada tahapan ini, kegiatan pengajaran bertujuan untuk membuat teks secara berkelompok. Pada contoh ragam aktivitas yang diberikan, siswa secara aktif mengasah empat skill dalam berbahasa, yaitu menyimak, berbicara, membaca, dan menulis. Sebagai contoh, siswa diminta untuk melakukan wawancara temannya terkait teks prosedur. Kemudian, mereka diminta untuk menuliskan hasil dari wawancara tesebut sebelum akhirnya didiskusikan dengan anggota kelompok. Secara berkelompok, siswa membuat teks prosedur yang kemudian dipresentasikan di kelas.

Tahapan akhir dari pengajaran ini adalah Independent Construction of the Text. Pada tahapan ini, siswa secara individu membuat teks prosedur. Setelah melewati tahapantahapan sebelumnya, siswa diharapkan sudah memiliki pengetahuan dan ketrampilan yang memadai untuk secara individu membuat teks prosedur. Akan tetapi, siswa masih dipandu untuk membuat kerangka teks prosedur yang akan mereka buat. Ragam pertanyaan terbimbing diberikan pada RPP guna mengarahkan siswa untuk membuat kerangka teks prosedur.

Pada contoh RPP yang diberikan, terdapat ragam sajian yang berbeda. Urutan kegiatan pada tiap tahapan kebanyakan memakai kata siswa. Hal tersebut bermaksud untuk mengedepankan student-centered learning dimana titik berat proses pembelajaran ada pada siswa, bukan guru. Kemudian, jenis evaluasi melibatkan jenis penilaian formatif seperti melalui tanya jawab dan diskusi, dan juga penilaian sumatif berbentuk proyek dan presentasi. Bentuk penilaian tersebut mendukung obyektifitas penilaian dan kebebasan berekspresi siswa. Kegiatan yang ada pada tiap tahapan juga dirancang agar siswa berkerja tidak hanya secara individu tetapi juga berkelompok. Dengan berkelompok, siswa akan belajar bekerjasama dan mengasah skill dalam menyimak, berbicara, menulis, dan membaca.

\section{KESIMPULAN}

Pendekatan Berbasis Teks sudah dipakai dalam pengajaran bahasa asing terutama bahasa Inggris. Akan tetapi, penggunaan pendekatan ini dalam pengajaran BIPA masih belum dimanfaatkan. RPP dengan pendekatan berbasis teks yang disajikan dapat dijadikan 
sebuah model pengajaran BIPA yang dapat memanfaatkan pendekatan berbasis teks dalam mengajarkan ragam teks kepada siswa. Selain memberikan salah satu referensi strategi pengajaran, pendekatan berbasis teks memberikan banyak keuntungan bagi siswa yang tercermin dari 4 tahapan utama yang ada dalam pendekatan berbasis teks.

Walapun tujuan akhir dari RPP yang disajikan adalah tulisan siswa dalam bentuk teks, tetapi kemampuan belajar siswa juga terasah. Pada setiap tahapan, mereka diminta untuk membaca ragam teks yang secara tidak langsung membelajarkan siswa. Pada keterampilan membaca, aktivitas menyampaikan pendapat, menjawab pertanyaan, dan presentasi adalah beberapa keterampilan yang siswa dapatkan dalam strategi pembelajaran berbasis teks. Bahkan, kemampuan memakai teknologi juga terasah dengan baik karena siswa diberikan kesempatan untuk memanfaatkan media daring seperti Internet dan peranti elektronik mereka. Oleh karena itu, untuk mengasah kemampuan secara maksimal, pengajar sangat berperan besar dalam kesuksesan belajar siswa. Pengajar tidak hanya bertindak sebagai pengajar, tetapi juga sebagai motivator dan pemberi masukan kepada siswa di tiap tahapan.

\section{DAFTAR RUJUKAN}

Ali, S., Idrees, M., \& Iftikhar, A. (2009). Effectiveness of Layered Instructional Strategy for teaching English at Secondary Level. i-Manager's Journal of Educational Technology, 6(1), 82-87.

American Council on the Teaching of Foreign Languages. (2012). ACTFL Pedoman Kemahiran 2012. Alexandria, VA.

Artayasa, I. M., Sutama, I. M., \& Utama, I. D. G. B.(2017). Pelaksanaan pembelajaran dengan menggunakan metode praktik langsung untuk siswa bipa beginner class di Yayasan Cinta Bahasa Indonesian language school. Jurnal Pendidikan Bahasa dan Sastra Indonesia Undiksha, 7(2).

Azaz, M. (2016). Integrating the Genre-Based Approach into teaching writing in Arabic as a foreign language. Journal of the National Council of Less Common Taught Languages 19, 31-60.

Azizah, R. F., Hs, W., \& Lestari, I. (2012). Pembelajaran Bahasa Indonesia bagi Penutur Asing (BIPA) Program CLS (Critical Language Scholarship) di Fakultas Sastra Universitas Negeri Malang Tahun 2012. Skripsi. Malang: Fakultas Sastra Universitas Negeri Malang.

Badger, R., \& White, G. (2000). A process genre approach to teaching writing. ELT journal, 54(2), 153-160.

Dickinson, P. (2013). A Genre-based Approach to preparing for IELTS and TOEFL essay writing tasks. Niigata University of International and Information Studies 16, 1-9.

Dirgeyasa, I. W. (2016). Genre-Based Approach: what and how to teach and to learn writing. English Language Teaching, 9(9), 45.

Farrell, T. (2002). Lesson planning. In Richards, J. C., \& Renandya, W. A. (Eds.). Methodology in language teaching: An anthology of current practice (pp. 30-39). Cambridge university press.

Hyon, S. (1996). Genre in three traditions: Implications for ESL. TESOL Quarterly, 30(4), 693-722.

Inderasari, E., \& Agustina, T. (2017). Pembelajaran Bahasa Indonesia pada mahasiswa asing dalam program BIPA IAIN Surakarta. Jurnal Pendidikan Bahasa dan Sastra Indonesia, 6(2), 6-15. 
Jazeri, M. (2016). Model perangkat pembelajaran keterampilan berbicara dengan pendekatan komunikatif kontekstual bagi mahasiswa asing. LITERA, 15(2), 217-226.

Kim, M. (2006). Genre-based approach to teaching writing. TESOL Working Paper Series, 4(2). 33-39.

Kusmiatun, A., \& Pratiwi, N. (2019) Reaktualisasi pelatihan ke-BIPA-an menuju penyelenggaraan kelas bipa yang berkualitas. Makalah pada Konferensi Internasional Pengajaran Bahasa Indonesia bagi Penutur Asing (KIPBIPA) XI.

Lunenburg, F. C., \& Irby, B. J. (2011). Instructional strategies to facilitate learning. International Journal of Educational Leadership Preparation, 6(4), 1-12.

Maharany, E.R. (2020). Pengembangan silabus pengajaran BIPA berbasis teks. Jurnal Pendidikan Bahasa dan Sastra, 10(1), 80-87.

Mayer, R. E. (2002). Rote versus meaningful learning. Theory into practice, 41(4), 226-232.

Nation, I. P., \& Macalister, J. (2010). Language curriculum design. New York, NY: Routledge.

NSW Department of School Education. (1989). The discussion genre. Erskineville, NSW: DSPPrintery.https://educationalsemiotics.files.wordpress.com/2012/11/tfw_discus sion_language_social_power.pdf

Nugroho, T. \& Hafrizon. (2009). Introduction to Genre Based Approach. https://mmursyidpw.files.wordpress.com/2009/05/introductiontogenrebasedappro ach.pdf

Reppen, R. (1994). A genre-based approach to content writing instruction. TESOL Journal, $4(2), 32-35$.

Richards, J. (2001). Curriculum development in language teaching. New York, NY: Cambridge University Press

Rosita, F. Y. (2019). Pengembangan teknik interactive-communicative games untuk keterampilan berbicara bipa kelas pemula. Jurnal Pendidikan Bahasa dan Sastra, 19(1), 51-60.

Sangoleye, S. A. (2016). A Critique of Selected Instructional Strategies in Higher Institutions in Nigeria. Journal of Education and Practice, 7(7), 78-84.

Sari, N. P. A. W., Sutama, I. M., \& Utama, I. D. G. B. (2016). Pembelajaran Bahasa Indonesia bagi Penutur Asing (BIPA) di Sekolah Cinta Bahasa, Ubud, Bali. Jurnal Pendidikan Bahasa dan Sastra Indonesia Undiksha, 5(3).

Sulistyarini, I. (2016). Implementasi Pembelajaran Keterampilan Berbicara pada Program Bahasa Indonesia Bagi Penutur Asing di Unit Pelayanan dan Pengembangan Bahasa Universitas Sebelas Maret Surakarta. Thesis. Surakarta: Universitas Sebelas Maret.

Tiawati, R., \& Lina, R. (2018). Perencanaan Pembelajaran Bahasa Indonesia Bagi Penutur Asing (BIPA) untuk Tingkat Pemula. Jurnal Gramatikal, 4, 393-402.

Turner, C. (2016). What matters most: using High-Traction Instructional Strategies to increase student success. NADE Digest, 9(1), 44-48.

Varuzza, M., Sinatra, R., Eschenauer, R., \& Blake, B. E. (2014). The Relationship between English Language Arts Teachers' Use of Instructional Strategies and Young Adolescents' Reading Motivation, Engagement, and Preference. Journal of Education and Learning, 3(2), 108-119.

Yang, Y. (2016). Teaching Chinese college ESL writing: A Genre-based Approach. English Language Teaching, 9(9), 36-44. 